Donald, H. B. \& IsaACs, A. (1954). J. gen. Microbiol. 10, 457-464.

\title{
Counts of Influenza Virus Particles
}

\author{
By HEATHER B. DONALD AND A. ISAACS \\ National Institute for Medical Research, Mill Hill, London, N.W. 7
}

SUMMARY: Particle counts of influenza virus preparations were made by two independent techniques; there was good agreement in the counts found by the two methods. Counts made on four strains of influenza virus and one strain of 'incomplete' virus showed that at the agglutination end-point there was about one virus particle per red cell. Parallel infectivity measurements of these strains made under optimal conditions showed that about ten virus particles corresponded to one ID50.

Many studies of the quantitative aspects of influenza virus growth have involved assumptions about the number of virus particles which constitute one infective dose. It has seemed worth while to test these assumptions by counting the number of virus particles seen by electron microscopy which correspond to one egg infective dose. Two independent techniques were used for making the particle counts, the first based on the spray technique used by Luria, Williams \& Backus (1951) in which counts are made of the virus particles mixed with polystyrene latex particles of known concentration, and the second based on the method of Dawson \& Elford (1949) in which the virus particles are adsorbed on red cell ghosts. In the spray technique the virus particles were counted before and after absorption with red blood cells and the difference gives the number of particles which should be specifically adsorbed to the red cell ghosts. This figure was found to correspond extremely well with the estimated number of virus particles on the surface of the red cell ghosts. In this way an estimate of the number of virus particles in different preparations of influenza virus was obtained, and this figure correlated with simultaneous measurements of the agglutination titre and infectivity of the preparation. This paper describes the results obtained.

\section{Materials}

Virus strains: Influenza A-PR8 (1934), Melbourne (MEL) (1935) and A/England/1/51 strains; Influenza B-Lee (1940). The virus seeds were stored in capillary tubes at $-65^{\circ}$.

Latex preparations. Polystyrene latex suspensions containing $1.55 \times 10^{13}$ particles/ml. were kindly supplied by Dr R. C. Backus. The particle concentration was checked from the weight of a dried sample of suspension and the mass of a single latex sphere as computed from measurements of density and diameter. Dilutions of $1 / 500$ of the standard suspension were found most suitable.

Bovine serum albumin. Armour Laboratories Crystallized Bovine Plasma Albumin.

Phosphate buffered saline, $0 \cdot 9 \% \mathrm{NaCl}, \mathrm{m} / 33$ phosphate, $\mathrm{pH} 6 \cdot 7$. 
Saponin. One $\mathrm{ml} .6 \%(\mathrm{w} / \mathrm{v})$ saponin was used to lake $75 \mathrm{ml}$. of a $1 \%(\mathrm{v} / \mathrm{v})$ suspension of red cells.

Sodium metaperiodate. Crystalline chemically pure $\mathrm{NaIO}_{4}(2 \cdot 14 \mathrm{~g}$.) dissolved in $1000 \mathrm{ml}$. of phosphate buffered saline to give a stock solution of $0.01 \mathrm{M}$. A dilution of $0.001 \mathrm{~m}$ was used to treat red cells.

Glycerol saline. Glycerol $1 \%(\mathrm{v} / \mathrm{v})$ in phosphate buffered saline.

Broth saline. Bacteriological (Hedley-Wright) broth diluted with an equal volume of normal saline.

Red cells. Fowls were bled from the wing vein into sodium citrate solution, the red cells washed thrice in normal saline, stored at $4^{\circ}$ and used within 3 days. For agglutination titrations the cells were made up in a $0.5 \%(\mathrm{v} / \mathrm{v})$ suspension in normal saline calibrated in a photoelectric densitometer.

\section{Methods}

Preparation of virus for testing. Precautions were taken to ensure that the virus used in these experiments was of high infectivity and was tested for infectivity under optimal conditions. Fertile eggs (10-day) were inoculated intra-allantoically with $0.05 \mathrm{ml}$. of a high dilution (von Magnus, 1946), usually $10^{-5}$, of seed virus. The eggs were incubated at $35^{\circ}$ and were harvested before the virus had reached its maximal titre in order to minimize deterioration in infectivity which might occur on prolonged incubation. Immediately after harvesting the infectivity and agglutination titres of the virus were measured, and some material was stored in capillary tubes at $-65^{\circ}$ for further tests at a later date. The remaining material was centrifuged lightly to remove tissue debris, dialysed overnight against distilled water and then used for spraying. Agglutination tests were carried out after centrifugation and dialysis so that any alteration in the concentration of virus as a result of these procedures could be observed. Usually there was no change in titre after centrifugation and dialysis, but sometimes a slight decrease in titre was found. In some experiments a large decrease in titre occurred after dialysis and such preparations were discarded. 'Incomplete' virus was prepared as described later.

Haemagglutination titration. Titrations were carried out in plastic plates and the results read by the pattern method. Serial twofold dilutions of virus $(0.25 \mathrm{ml}$.$) were made in saline, and an equal volume of 0.5 \%(\mathrm{v} / \mathrm{v})$ chick red cells added. The cells were allowed to settle and the agglutination endpoint taken as the tube showing partial (i.e. slight but clearly detectable) agglutination. Where the partial agglutination end-point was not visible it was obtained by interpolation. Since many workers have used $1 \%$ red cell suspensions, the titres obtained were adjusted so that they express the number of agglutinating doses per ml. of virus for $0.25 \mathrm{ml}$. of $1 \%$ red cells.

Infectivity titration. In the preliminary titration serial tenfold dilutions of virus were prepared in chilled broth saline and $0.05 \mathrm{ml}$. amounts of $10^{-7}$, $10^{-8}, 10^{-9}$ dilutions were inoculated by the allantoic route into groups of five 10- to 12-day eggs. In a second titration with virus stored at $-65^{\circ}, 3 \cdot 16$-fold dilutions were chosen around the end-point and five groups of four eggs were 
used. The eggs were incubated for $72 \mathrm{hr}$, at $35^{\circ}$ and then tested for agglutinins. The EID 50 was calculated by the method of Reed \& Muench (1938) and the average of the two titrations was used to calculate the number of EID 50/ml. of original material. Agreement between the two titrations was fairly good; on the average the second titration gave a value of $0 \cdot 17 \pm 0 \cdot 45 \log$ units lower than the first.

Virus particle assay by spraying technique. A gun similar to that of Luria, et al. (1951) was used. It consisted of two concentric glass tubes, the inner tube being drawn out to a fine bore with uniform end cross-section of approximately $0.15 \mathrm{~mm}$., and the outer tube having an inlet for air under pressure. A pressure of $20 \mathrm{lb}$./sq.in. was used and, to diminish turbulence, the specimen grids were mounted on a thin upright support at a distance of $11 \mathrm{in.} \mathrm{from} \mathrm{the}$ tip of the gun. The preparation to be examined was mixed with a measured sample of the polystyrene latex suspension to give a final concentration of $\mathbf{3} \cdot \mathbf{1} \times \mathbf{1 0}^{10}$ latex particles/ml. Before spraying a few crystals of purified bovine serum albumin were added to give a concentration of about $0.001 \%(w / v)$ and this helped to mark the edges of the droplet patterns clearly. Preparations were mixed thoroughly by pipetting, sprayed immediately on to collodioncoated grids and shadowed with gold-manganin before being examined in the electron microscope. The gun was washed thoroughly with distilled water between the examination of various strains.

Counts were made of the number of influenza virus particles in individual drops, several hundred particles of each type being counted in each experiment. To test whether a particular ratio of influenza virus to latex particles was significantly constant throughout an experiment, the correlation coefficient $(r)$ between the counts of particles of the two types in individual droplets was calculated. A high and significant correlation was found in all the experiments quoted (i.e. $r>0.6 ; P<0.01$ ).

To test the specificity of the influenza virus particles counted, a measured sample of the infected allantoic fluid was absorbed with red blood cells as in the next technique. The supernatant from this was dialysed overnight against distilled water and then mixed with polystyrene latex and sprayed as above. Usually this absorption removed the great majority of virus particles from the allantoic fluid.

Virus particle assay by red cell absorption technique. Fowl red blood cells were haemolysed with saponin and washed thoroughly with phosphate buffered saline. Influenza-infected allantoic fluid was spun lightly to remove any blood cells or tissue debris and then mixed with the red cell ghosts. The ghosts were treated before contact with the virus with $0.001 \mathrm{M}$-sodium metaperiodate solution (Fazekas de St Groth, 1948) a treatment which modifies the receptors on the surface of the cell membrane in such a way that virus absorption is unimpaired while elution is almost completely prevented. Absorption and all subsequent washings were carried out at $0^{\circ}$. After an hour's contact with the infected allantoic fluid the cells were centrifuged at $2500 \mathrm{rev} . / \mathrm{min}$. for $5 \mathrm{~min}$. and the supernatant fluid removed. The cells were then resuspended in phosphate buffered saline fixed in $0.1 \%$ osmic acid for 
30 min., washed with distilled water and mounted on electron microscope grids coated with collodion. The final distilled water washings were carried out at low speed (500 rev./min.) and the ghosts mounted carefully from very dilute suspensions so that flatly mounted cells relatively free from wrinkles and swelling of the nucleus were obtained. Specimens were examined in the electron microscope by direct transmission and after shadowing with goldmanganin. Counts were made of the average number of virus particles per red cell ghost assuming a random distribution of particles over the membrane. This assumption was justified by counts made of the numbers of particles present in ruled areas of the ghost surface; the distribution of particles in these areas did not differ significantly from that expected on the Poisson distribution (see Pl. 2, fig. 4). Only those particles which cast a shadow were counted and identified as being on the top surface of the membrane. Areas to which particle counts referred were measured directly from the electron micrographs, by using transparent graph paper. In order to obtain an estimate of the total number of particles/red cell, the figure obtained was increased to allow for the total countable area, then increased by $15 \%$ to allow for the area masked by the nucleus, and finally doubed for the reverse side of the ghost. The total number of ghosts used in a particular preparation was counted in a haemocytometer cell and thus a figure was obtained for the number of virus particles in one $\mathrm{ml}$. of the original allantoic fluid.

Electron microscopy. A Siemens Electron Microscope was used with $70 \mu$. objective aperture and an accelerating voltage of $50 \mathrm{kV}$. A magnification of 5000 on the screen was used for most micrographs. Some of the later micrographs were taken with a new Siemens machine using a $50 \mu$. objective aperture.

\section{RESULTS}

The results of electron microscopy are illustrated in Pl. 1, figs, 1, 2 and Pl. 2, figs. 3, 4. Pl. 1, fig. 1, shows a microdrop containing influenza virus and latex particles, and a corner of this microdrop is shown at a higher magnification in Pl. 1, fig. 2. The latex particles are about $250 \mathrm{~m} \mu$. in diameter and extremely regular in size and shape. The smaller virus particles, of about $100 \mathrm{~m} \mu$. diameter, could be counted easily after a little practice. They were of characteristic appearance and were removed from the microdrops by absorption with red cells; Pl. 2, fig. 3, shows the appearance after absorption with red cells. Pl. 2, fig. 4, shows the virus particles now adsorbed on the surface of the red cell ghost. In a few preparations, occasional clumps of about five to six particles were seen in sprayed material, but never in virus adsorbed on the red cell surface; the particles in such clumps were counted individually. Occasional filaments were seen in preparations of MEL and incomplete PR 8 virus, and they were common with $\mathbf{A} /$ England/1/51 virus; the filaments were counted singly.

Table 1 shows the complete results of a single experiment with the strain MEL. In order to assess the results of an experiment a number of ratios were calculated: the ratio of particles counted/agglutinating dose by the two counting techniques used; the ratio of infective doses/agglutinating dose when 
infectivity was measured at the beginning of the experiment under optimal conditions; the ratio of virus particles/infective dose, obtained by dividing the first ratio by the second. Estimates of the ratio of particles counted/aggluti-

\section{Table 1. Counts of particles, egg-infectivity and agglutinating titres of a preparation of $M E L$ virus}

$\begin{array}{ll}\text { Particle count/ml. by spray technique } & 10^{10 \cdot 7} \\ \text { Particle count/ml. by red cell absorption technique } & 10^{10 \cdot 8} \\ \text { Haemagglutinin titre/ml. of original virus } & 10^{3 \cdot 7} \\ \text { Haemagglutinin titre/ml. of sprayed material } & 10^{9 \cdot 6} \\ \text { Haemagglutinin titre/ml. of adsorbed virus } & 10^{3 \cdot 6} \\ \text { Infectivity titre/ml. of original virus } & 10^{9 \cdot 9}\end{array}$

nating dose by the two techniques showed an extremely good agreement; the spray technique gave a value of $0 \cdot 07 \pm 0 \cdot 15 \mathrm{log}$ unit higher than the red cell technique. In general, however, we have preferred to put greater weight on the counts obtained by the spraying technique since it involved fewer assumptions.

Table 2. Ratio of particles/agglutinating dose

\begin{tabular}{lcccc}
\multicolumn{1}{c}{ Strain } & Description & \multicolumn{3}{c}{ Ratio (log) } \\
PR 8 & A 1934 & $7 \cdot 3$ & $7 \cdot 4$ & $7 \cdot 2$ \\
MEL & A 1935 & $7 \cdot 1$ & $7 \cdot 3$ & $7 \cdot 1$ \\
A/England/1/51 & A 1951 & $7 \cdot 3$ & $\mathbf{7 \cdot 1}$ & $6 \cdot 9$ \\
Lee & B 1940 & $7 \cdot 3$ & $7 \cdot 3$ & $7 \cdot 2$ \\
Incomplete PR8 & 3rd undiluted & $\mathbf{7 \cdot 3}$ & $\mathbf{7 \cdot 2}$ & $\mathbf{7 \cdot 2}$ \\
& passage & & &
\end{tabular}

Table 2 shows the ratio of the number of virus particles counted by the spray technique to the number of agglutinating doses $/ \mathrm{ml}$. of suspensions of four strains of influenza virus. The results of three experiments with each strain are presented and in addition preparations of 'incomplete' virus (von Magnus, 1946) of strain PR 8 were also examined. The ratios were surprisingly constant and, with two exceptions, varied between $10^{7 \cdot 1}$ and $10^{7 \cdot 3}$ with an overall mean of $10^{7 \cdot 21}$. There was as great a variation between different measurements of a single strain as between different strains of virus. Counts of the number of red cells in $0.25 \mathrm{ml}$. of a $1 \%$ suspension of red cells gave figures of $10^{7 \cdot 1}$ to $10^{7 \cdot 2}$; hence we conclude that at the agglutination end-point there was about one virus particle/red cell, with the strains we used.* The lowest ratio found was with a strain of $\mathbf{A} /$ England/1/51 virus in which there were numerous filamentous forms and we have other evidence to suggest that this factor may lower the ratio.

Table 3 shows the ratio of infective doses (ID 50)/agglutinating dose for the same preparations. The ratios in most experiments do not differ greatly from those found by other workers (e.g. von Magnus, 1951; Fazekas de St Groth \& Cairns, 1952), although two preparations of PR8 on repeated titration gave rather lower ratios. When these two preparations are excluded, the mean ratio of ID50 dose/agglutinating dose for the other 'complete' virus strains was

* Dr R. W. Schlesinger and Dr G. Werner tell us that they have reached a similar conclusion from counts made by the red cell technique. 
Table 3. Ratio of egg infective doses/agglutinating dose

\begin{tabular}{lcccc}
\multicolumn{1}{c}{ Strain } & Description & \multicolumn{3}{c}{ Ratio (log) } \\
PR8 & A 1934 & $5 \cdot 7$ & $6 \cdot 2$ & $5 \cdot 3$ \\
MEL & A1935 & $6 \cdot 2$ & $6 \cdot 0$ & $6 \cdot 2$ \\
A/England/1/51 & A1951 & $6 \cdot 2$ & $6 \cdot 1$ & $6 \cdot 1$ \\
Lee & B 1940 & $6 \cdot 2$ & $6 \cdot 2$ & $5 \cdot 9$ \\
Incomplete PR 8 & 3rd undiluted & $4 \cdot 2$ & $4 \cdot 4$ & $4 \cdot 2$
\end{tabular}

$10^{6 \cdot 13}$. Slight differences in the ratio found by different workers might depend on the particular agglutination end-points used. The 'incomplete' PR8 was obtained by making three passages of undiluted allantoic fluid at $24 \mathrm{hr}$. intervals (von Magnus, 1951). The ratios obtained with 'incomplete' PR8 have been consistently lower than those found with standard virus, but have never been so low as those obtained by von Magnus (1951). This finding has been made in our laboratory on a number of occasions, and we do not yet know whether the difference from von Magnus's results is due to virus or egg variation, or to other causes.

Table 4. Ratio of particles/egg infective dose

\begin{tabular}{lcccc}
\multicolumn{1}{c}{ Strain } & Description & \multicolumn{3}{c}{ Ratio (log) } \\
PR 8 & A 1934 & $1 \cdot 6$ & $1 \cdot 2$ & $1 \cdot 9$ \\
MEL & A 1935 & 0.9 & $1 \cdot 3$ & 0.9 \\
A/England/1/51 & A1951 & $1 \cdot 1$ & $1 \cdot 0$ & $0 \cdot 8$ \\
Lee & B 1940 & $1 \cdot 1$ & $1 \cdot 1$ & $1 \cdot 3$ \\
Incomplete PR8 & 3rd undiluted & $3 \cdot 1$ & $2 \cdot 8$ & $3 \cdot 0$ \\
& passage & & &
\end{tabular}

Table 4 shows the ratio of virus particles/ID50 dose for the same strains. With the standard strains the ratios found were all of the order of 10 particles/ID50 dose, and for 'incomplete' PR 8 the figure was about 1000.

\section{DISCUSSION}

Measurements of the number of virus particles per infective dose with a strain of bacteriophage by Luria et al. (1951) showed that one virus particle corresponded roughly to one infective dose. Previously Friedewald \& Pickels (1944) calculated that about ten virus particles corresponded to one infective dose. This figure was reached as a result of estimates of the weight of a virus particle from a knowledge of its particle size and density. However, their conclusion has not been generally accepted (e.g. Henle, 1950). Their technique was similar to that of Smadel, Rivers \& Pickels (1939) who found that, on the average, $4 \cdot 2$ vaccinia virus particles corresponded to one infective dose.

Another method of estimating the number of influenza virus particles/infective dose was that of Fazekas de St Groth \& Cairns (1952) who measured the percentage of eggs which became infected after inoculation with closely spaced dilutions of virus. Their experimental dosage-response curve was less steep than that of a theoretical curve based on the assumptions that one virus particle was sufficient to initiate infection and that there was no factor of 
host variation. They interpreted this result to mean that one virus particle might be sufficient to initiate infection but that there was also a factor of host resistance which tended to lower the probability of infection. However, the experimental result might equally be interpreted on the assumption that considerably more than one virus particle was required to initiate infection and that there was a correspondingly greater factor of host resistance. This interpretation has experimental support since Fulton \& Armitage (1951) found that the slopes of the dosage-response curves in infectivity titrations of influenza virus by egg and tissue culture techniques did not differ significantly, although the tissue culture technique is roughly $\mathbf{4 0}$ times less sensitive than the egg technique. In view of this and of the present findings it may be, therefore, that some of the conclusions reached by Cairns, Fazekas de St Groth \& Edney (1952) require re-interpretation.*

One implication of our results concerns ideas about 'incomplete' virus. Such a name now seems inappropriate if ten particles of 'complete' virus are required to initiate infection. At present we have no information on whether preparations of 'complete' and 'incomplete' virus contain fully infective and fully non-infective virus in different proportions. It would seem more appropriate, therefore, in the present state of knowledge, to refer to preparations of virus as having a given probability of initiating infection. Thus, in our experiments standard virus would contain particles with a probability of about $0 \cdot 1$ and 'incomplete' virus, particles with a probability of about $0 \cdot 001$, of initiating infection. Description in these terms does not commit us to any theory of the mechanisms which govern the probability of initiating infection in advance of information.

Another implication of our results concerns the yield of virus from a single infective dose. Henle, Henle \& Rosenberg (1947) found that, on the average, a single infective dose yielded about 100 infective doses after one 'cycle' of multiplication; further 'cycles' were prevented by a 'blocking' dose of inactive influenza virus. In view of the present results it would appear that one infective dose, or ten virus particles, yielded about 1000 virus particles in a single cycle. Of the ten infecting particles, however, only one particle on the average would initiate infection. Hence, the 'burst size', estimated as the number of virus particles resulting from infection by one virus particle in one 'cycle' of multiplication would be about 1000 on the average.

The methods which we have used for measuring the infectivity of influenza virus are the most sensitive in general use at present. However, Liu \& Henle (1953) have shown that some eggs injected with small doses ( $\frac{1}{4}-\frac{1}{8}$ ID 50) of influenza virus may show no agglutinin after incubation for $\mathbf{7 2} \mathrm{hr}$. but may yet reveal virus on inoculation into further eggs. This finding, in keeping with the present results, focuses attention on the factors which govern the probability of initiating infection. Elucidation of these factors might help greatly the understanding of the processes of influenza virus multiplication.

* Luria (1953) states: "The numerical relation between successful particles cannot be decided by titration or by any other statistical tests, but only by actual counts or determinations of particle numbers." 
We should like to thank Dr Forrest Fulton with whom we have had many valuable discussions on this work. It is a pleasure to acknowledge the technical help given by Mrs I. M. Honey, Mr O. Green and Mr E. Owen.

\section{REFERENCES}

Cairns, H. J. F., Fazekas de St Groth, S. \& Edney, M. (1952). Quantitative aspects of influenza virus multiplication. J. Immunol. 69, 155.

Dawson, I. M. \& ELForD, W. J. (1949). The investigation of influenza and related viruses in the electron microscope, by a new technique. J.gen. Microbiol. 3, 298.

Fazekas de St Groth, S. (1948). Modification of virus receptors by metaperiodate. I. The properties of $\mathrm{IO}_{4}$-treated red-cells. Aust. J. exp. Biol. med. Sci. 27, 65.

Fazekas de St Groth, S. \& CaIrns, H. J. F. (1952). Quantitative aspects of influenza virus multiplication. IV. Definition of constants and general discussion. J. Immunol. 69, 173.

Friedewald, W. F. \& Pickels, E. G. (1944). Centrifugation and ultrafiltration studies on allantoic fluid preparations of influenza virus. J. exp. Med. 79, 301.

Fulton, F. \& Armitage, P. (1951). Surviving tissue suspensions for influenza virus titration. J. Hyg., Camb. 49, 247.

Hente, W. (1950). Interference phenomena between animal viruses: a review. J. Immunol. 64, 203.

Henle, W., Henle, G. \& Rosenberg, E. B. (1947). The demonstration of one-step growth curves of influenza viruses through the blocking effect of irradiated virus on further infection. J. exp. Med. 86, 423.

Liu, O. C. \& Henle, W. (1953). Studies on host-virus interactions in the chick embryo-influenza virus system. VII. Data concerning the significance of infectivity titration end-points and the separation of clones at limiting dilutions. J. exp. Med. 97, 889.

Luria, S. E. (1953). General Virology. New York: John Wiley \& Sons Inc.

Luria, S. E., Williams, R. C. \& Backus, R. C. (1951). Electron micrographic counts of bacteriophage particles. J. Bact. 61, 179 .

Magnus, P. von (1946). Studies on interference in experimental influenza. I. Biological observations. Arkiv. Kemi Min. Geol. 24 B, 1.

Magnus, P. von (1951). Propagation of the PR 8 strain of influenza A virus in chick embryos. II. The formation of 'incomplete' virus following inoculation of large doses of seed virus. Acta path. microbiol. scand. 28, 278.

Reed, L. J. \& Muench, H. (1938). A simple method of estimating fifty per cent endpoints. Amer. J. Hyg. 27, 493.

Smadel, J. E., Rivers, T. M. \& Pickels, E. G. (1939). Estimation of the purity of preparations of elementary bodies of vaccinia. J. exp. Med. 70, 379.

\section{EXPLANATION OF PLATES}

\section{Prate 1}

Fig. 1. Microdrop containing polystyrene latex and Lee strain of influenza virus. The larger dense spheres are the latex particles, the small flatter particles indicated by arrows are the elementary bodies of the virus. Gold-manganin shadowed. $\times \mathbf{7 , 5 0 0}$.

Fig. 2. Portion of a field similar to that of fig. 1 showing two latex and two virus particles. Gold-manganin shadowed. $\times 30,000$.

\section{Plate 2}

Fig. 3. Microdrop showing infected allantoic fluid after absorption with red cells. Polystyrene latex particles but no influenza virus particles are present. Gold-manganin shadowed. $\times 10,000$.

Fig. 4. Particles of Lee strain of influenza virus adsorbed on to a red cell ghost. Goldmanganin shadowed. $\times 10,000$. 
Journal of General Microbiology, Vol. 10, No. 3
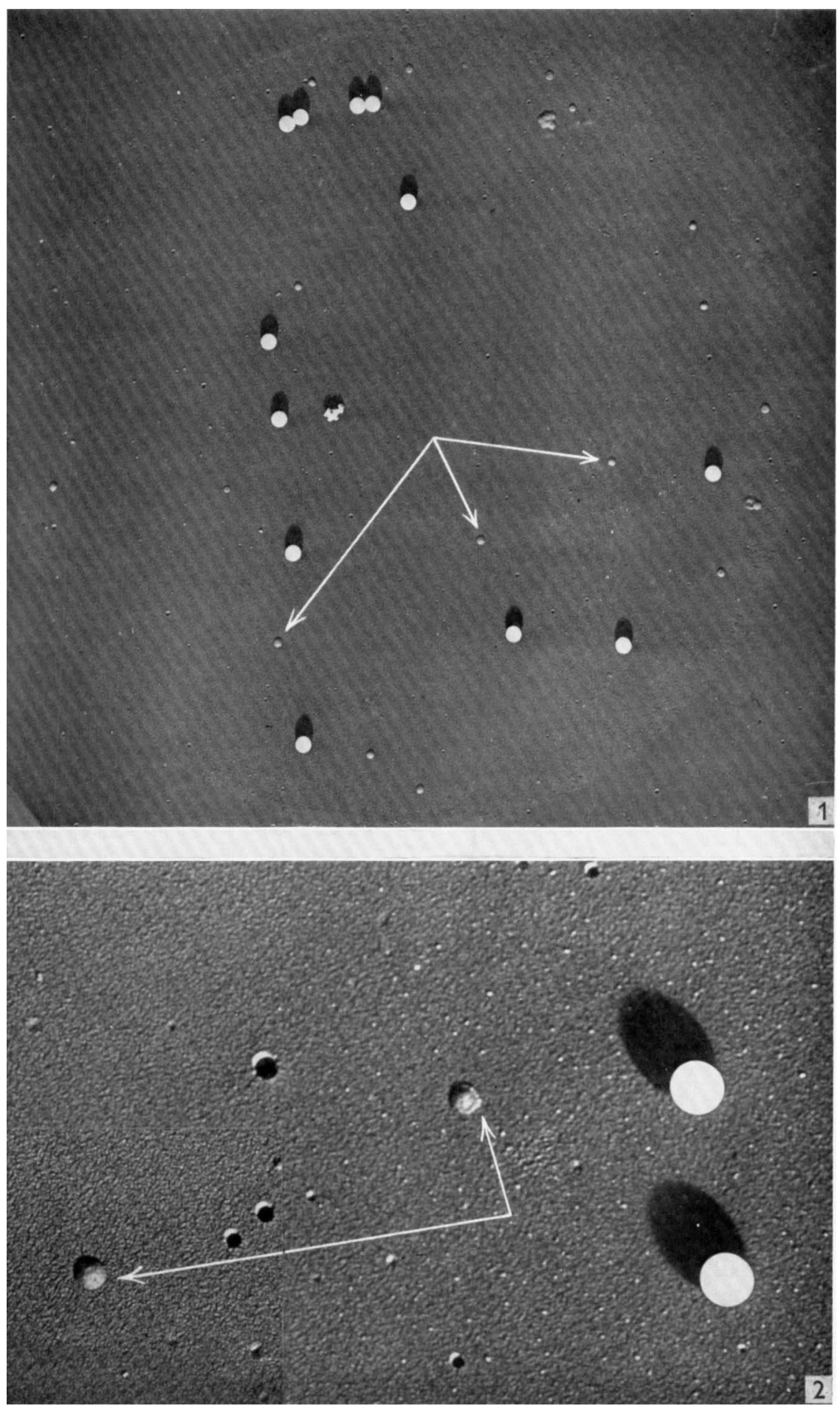

H. B. Donald \& A. Isaacs-Counts of influenza virus particles. Plate 1 
Journal of General Microbiology, Vol. 10, No. 3
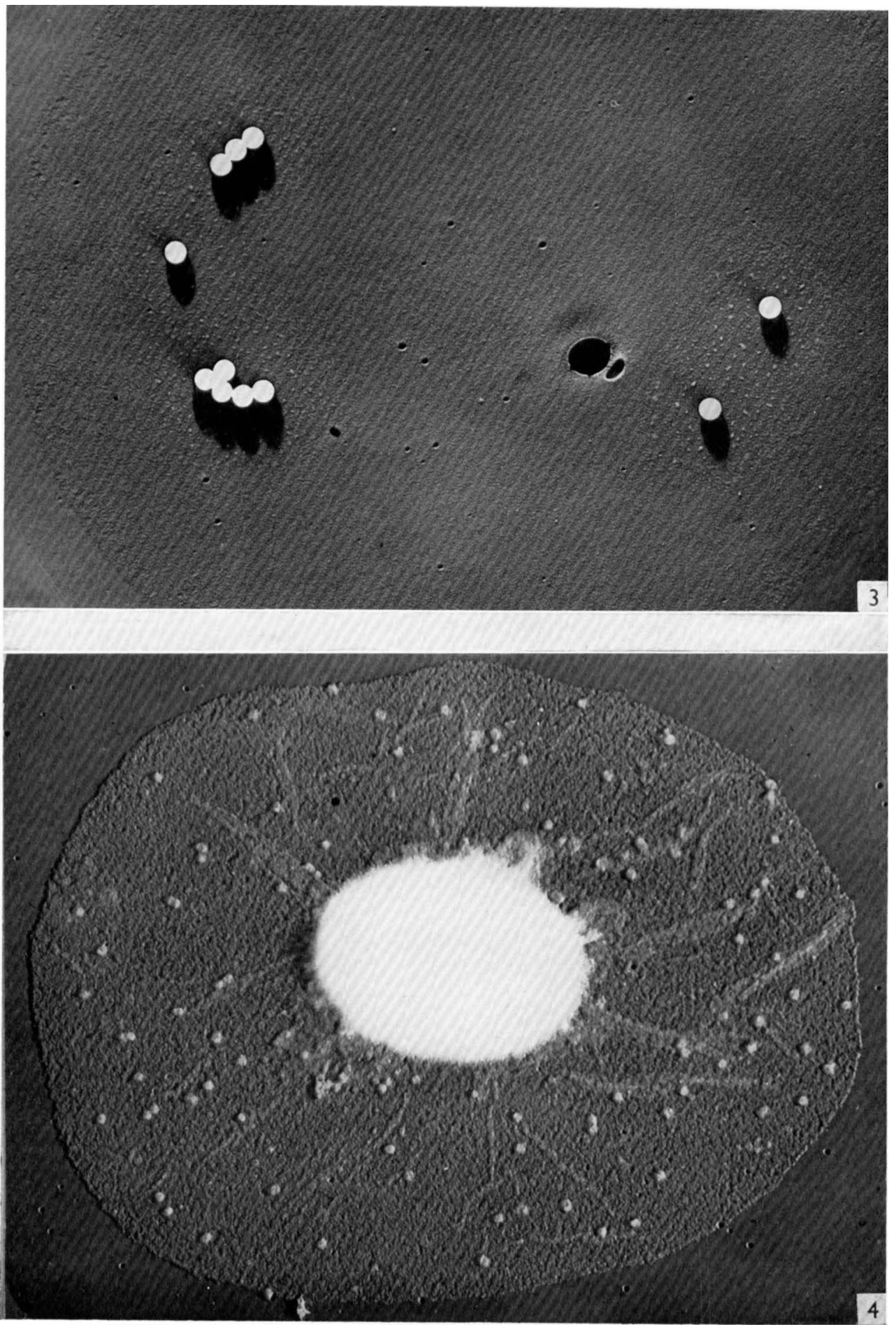

H. B. Donald \& A. Isaacs-Counts of influenza virus particles. Plate 2 